\title{
Validation of GLASOD Map for Sediment Sources and Erosion Processes Identification in the Nyumba Ya Mungu Reservoir Catchment
}

\author{
Preksedis Marco Ndomba \\ Department of Water Resources Engineering, University of Dares Salaam, Dares Salaam, Tanzania \\ Email: pmndomba@udsm.ac.tz
}

Received 5 July 2015; accepted 13 September 2015; published 16 September 2015

Copyright (C) 2015 by author and Scientific Research Publishing Inc. This work is licensed under the Creative Commons Attribution International License (CC BY). http://creativecommons.org/licenses/by/4.0/

(c) (i) Open Access

\section{Abstract}

The main objective of this paper is to report on the preliminary validation results of the Global Assessment of Soil Degradation (GLASOD) as a tool for mapping sediment sources in Tanzania. This study was carried out in a well studied catchment, the Nyumba Ya Mungu (NYM) reservoir catchment located in the upstream of Pangani River Sub-basin. Previous studies in the same catchment used quantitative approach that entailed comprehensive sediment sampling programme and numerical modelling to identify sediment sources and erosion processes. Although previous researchers' findings were satisfactory, the methods used were demanding in terms of resources (time, funding, and personnel) and impractical to a large ungauged catchment. The quest to validate GLASOD map is evident as it was qualitatively developed through collating expert judgments of many soil scientists to produce a world map of human-induced soil degradation at a scale 1:10,000,000. In the current study sediment sources mapped from qualitative method (GLASOD) plus supplement field visit observations and quantitative approaches are compared and discussed in detail. Preliminary results suggest that the paired information on sediment sources, field based data versus GLASOD, for upper catchments or upland locations are more strongly correlated than lower reaches. The results of this study have further emphasized the fact that GLASOD map is satisfactory to depict large regional differences in soil degradation but it is not capable of explaining local degradation. Besides, GLASOD map does not capture erosion processes dynamics compared to comprehensive sediment sampling programme. Notwithstanding, GLASOD map might be a useful tool for sediment sources and erosion processes identification scoping studies in the study area. Based on this study, it is therefore recommended to complement the GLASOD map with field based data for detailed study initiatives. 


\section{Keywords}

\section{GLASOD, Erosion Processes, Sediment Sources, Soil Degradation, Validation}

\section{Introduction}

An ideal way to identify sediment sources and erosion processes as suggested in literature would be to collect the sediment flow data spatially, at least from each of the river tributaries. Such a research project would definitely be demanding in terms of resources (i.e., time, funding and personnel) and logistical issues [1]-[3]. Information on sediment sources may be required for a number of purposes. Erosion types mapping is one of the most important and basic methods in erosion and sediment yield studies to determine suitable soil conservation programmes [4]. Although soil degradation is recognized as a very widespread problem, its geographical distribution and total area affected are only very roughly known [3] [5]. It is therefore imperative to study the sediment production and transport processes within Tanzania in order to enhance water resource management.

A number of indirect and direct methods exist for evaluating sediment sources and erosion processes. As an example of indirect method, it may be possible to estimate the total sheet and rill erosions within a drainage basin using a soil loss equation, such as the Universal Soil Loss Equation (USLE), and to estimate the downstream yield from this source by applying a sediment delivery ratio. Subtraction of the calculated soil erosion loss, corrected for sediment delivery, from the measured yield, gives an estimate of the contribution from other sources such as gully and channel erosions. The reliability of the results from the latter approach has been doubted by many scientists including [6]. It could lead to a biased result in case of mismatch between conceived erosion processes by the modeller and a tool used to estimate erosion [3].

Another more elaborative indirect method available to date applied by many workers is the fingerprinting technique. This method is based on the principle that sediments in suspension maintain some of the geochemical properties of their source material, and that these properties can thus be used as tracers [7]. The tracers that have been applied by many researchers include Soil Organic Matter (SOM) content and chemically conservative tracer, Caesium-137 [7] [8]. However, the use of tracers to evaluate sediment source is not without difficulties [6]. Problems may arise in relating source material to suspended sediment, because of selective nature of the erosion and transportation process, which causes enrichment of suspended sediment in fines and organic matter. Other workers such as [8] successfully applied the fingerprint technique using organic matter content and particle size distribution of the reservoir deposits to infer sources of sediments in a basin in central parts of Tanzania.

A basic relationship between concentration of suspended sediment (C) and water discharge (Q) during single hydrologic events has been used by [9] as indirect method to identify sediment sources. However, the potential mix and interrelationships of these and other variables present a formidable challenge to predicting the type and magnitude of C-Q relation for a particular site and occasion [9].

In the case of the direct approach, as critically reviewed by [3] [10], an attempt is always made to isolate major sediment sources within the drainage basin and to monitor the rate of sediment production. For instances, erosion pins could be used to document surface lowering; and pins, surveying and terrestrial photogrammetry could be used to estimate sediment production by bank erosion. Besides, results from direct methods, which tend to focus at small-scale plot are un-reliable and may not be easily extrapolated to larger scale such as a catchment [6] [11].

With the background thereof, one could deduce that there are no compelling methods on sediment sources identification. In response to the deadlock, researchers in Tanzania and the region have been continuously testing various complementary study frameworks such as hydrological variable mapping technique [2]. In this technique rainfall is conceived as a trigger and driver of runoff and sediment. The spatially distributed nature of the rainfall stations in the catchment are correlated to sediment sources in the spatial domain. The approach indirectly imitates distributed modelling philosophy, but here correlation of the variables and sediment concentrations gives more insight into the location-based sediment sources and erosion processes as well. Besides, the technique analyzes the seasonal sediment delivery fluxes responses. The hydrological variable mapping technique could complement results of other methods' findings such as rating loops and fingerprinting with spatial and temporal correlation of rainfall and runoff information to identify erosion sources and processes. However, 
it has been advised by [2] that for in-depth understanding of the erosion sources and processes at the catchment level the hydrological variable mapping technique should not be applied in isolation. Notwithstanding the improved performance in sediment sources identification, still the method is limiting in terms of logistical issues and resources. Therefore a more elegant and cheap methodology is being sought of.

It should be noted that a Global Assessment of Soil Degradation (GLASOD) map was developed in late 1980's in ad-hoc manner, on a basis of incomplete knowledge, as a matter of urgency [5]. A world map on the status of human-induced soil degradation was prepared and published based on soil scientists' opinion on soil degradation in their particular regions across the world. The exercise was guided by common principles. By then it was imperative to have an assessment of good quality immediately instead of having an assessment of very good quality a bit later [5]. GLASOD is one of the qualitative approaches of mapping erosion features. Qualitative erosion mapping approaches are normally adapted to regional characteristics and data availability [4]. Having doubted the reproducibility of GLASOD map to unvisited sites, [1] decided to empirically validate it using qualitative data/information. They wanted to answer the question "how good is the GLASOD". It was concluded in their study that the expert assessments in GLASOD were not very reliable. However, [1] went further recommending future work that will give quantitative interpretation to the qualitative assessments by relating their ordered classes to a quantitative measure of land degradation. Therefore, in the current study GLASOD map is being tested in one of the well studied catchments in Tanzania, the Nyumba Ya Mungu Reservoir catchment, as a potential elegant and cheap methodology using quantitative data. Although some researchers have had attempted using GLASOD map in the region, lack of validation data limited its application [12].

\section{Material and Methods}

\subsection{Study Area Description}

This study uses a case study approach to adequately validate the readily available GLASOD map [13] in a well studied catchment, where sediment sources have been mapped using field based data and quantitative methods. The experiment was performed in the catchment in which, the author has personally been involved in various initiatives including training, research, and consultancy services. Therefore, it is a case study site on which the author is well acclimatized and knowledgeable, and where sediment flow data are readily available.

The case study area, Nyumba Ya Mungu reservoir catchment, is located in the upstream of Pangani River Ba$\sin$ (PRB), in the North-eastern part of Tanzania and covers an area of about 12,000 $\mathrm{km}^{2}$ [10] (Figure 1(a)). It is located between Latitudes $3^{\circ} 00^{\prime} 00^{\prime \prime}$ and $4^{\circ} 3^{\prime} 50^{\prime \prime}$ South, and Longitudes $36^{\circ} 20^{\prime} 00^{\prime \prime}$ and $38^{\circ} 00^{\prime} 00^{\prime \prime}$ East. The two main tributaries, the Kikuletwa (1DD1) and the Ruvu (1DC1) (Figure 1(a)), join at Nyumba Ya Mungu (NYM), a reservoir of about $140 \mathrm{~km}^{2}$ area coverage.

The main sub-catchments in the study area are Weruweru, Kikafu, Sanya, Upper Kikuletwa, Rau, Mue, Himo, Lake Jipe, and Mount Meru slopes. This area has an average annual rainfall of about $1000 \mathrm{~mm}$. The rainfall pattern is bimodal with two distinct rainy seasons, the main rainy season from March to June and the shorter rainy season from October to December. The altitude in the study area ranges between 700 and 5825 m.a.s.l. with Mount Killimanjaro peak as the highest ground. However, the lowlands terrain dominates with coverage of about 73\% [10]. Based on the Soil Atlas of Tanzania, the main soil type in the study area is clay with good drainage (Figure 1(b)). Actively induced vegetation, forest, bushland and thickets with some alpine desert chiefly characterize the land cover of the catchment.

\subsection{Sediment Sources Identification Using Qualitative Approach, GLASOD Map}

\subsubsection{GLASOD Concept}

Global Assessment of Soil Degradation (GLASOD) mapping was first carried out by the International Soil Reference and Information Centre (ISRIC) [13]. GLASOD collated the expert judgments of many soil scientists to produce a world map of human-induced soil degradation at scale 1:10,000,000. Using uniform guidelines, data were compiled on the status of soil degradation considering the type, extent, degree, rate and causes of degradation within physiographic units (Table 1 \& Table 2). The status of soil degradation is an expression of the severity of the process. The severity of the process is characterized by the degree in which the soil is degraded and by the relative extent of the degraded area within a delineated physiographic unit [5]. A total of 12 soil degradation types are recognized on the GLASOD map. They are grouped into four main types (water erosion; wind 


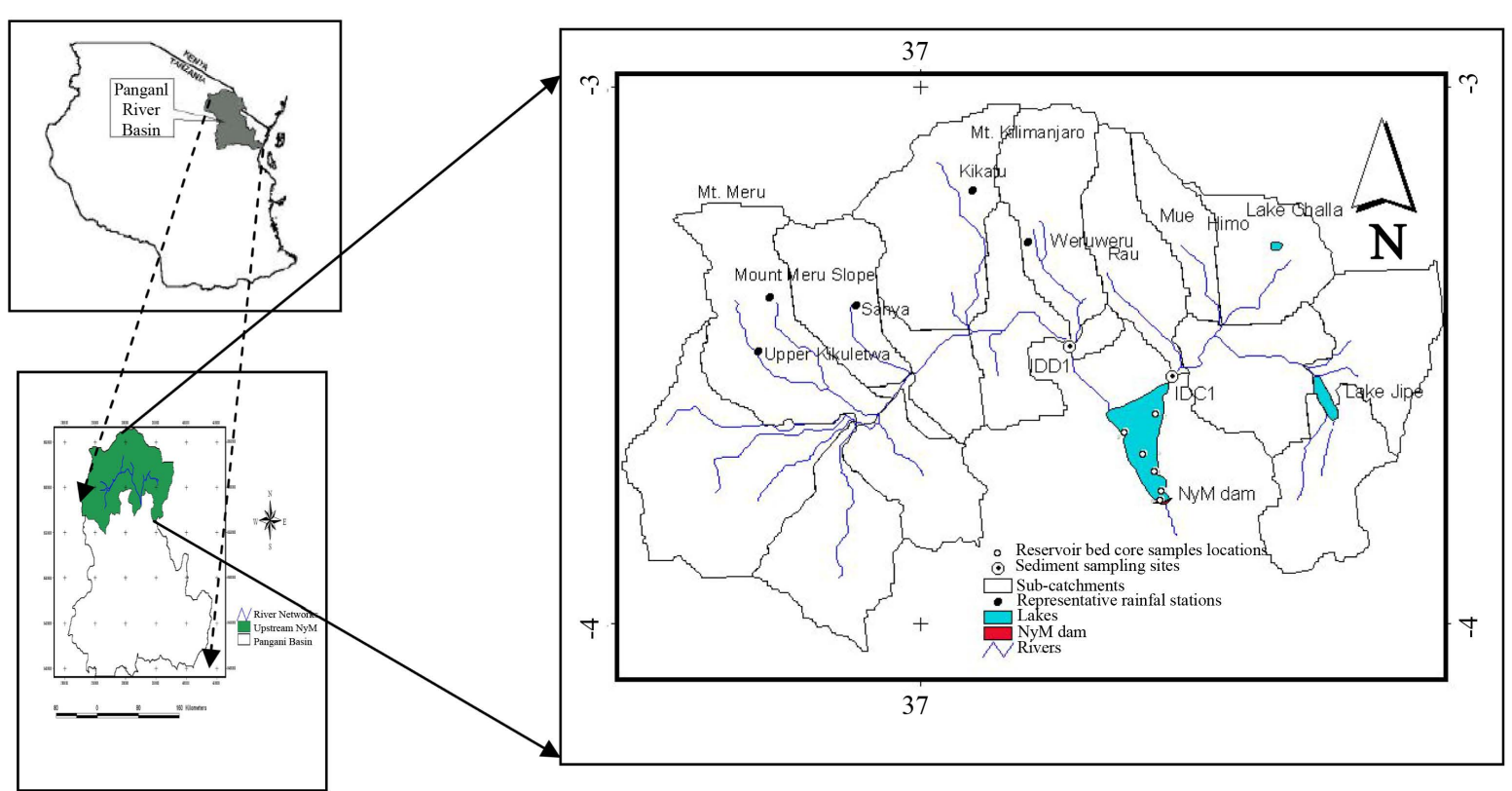

(a)

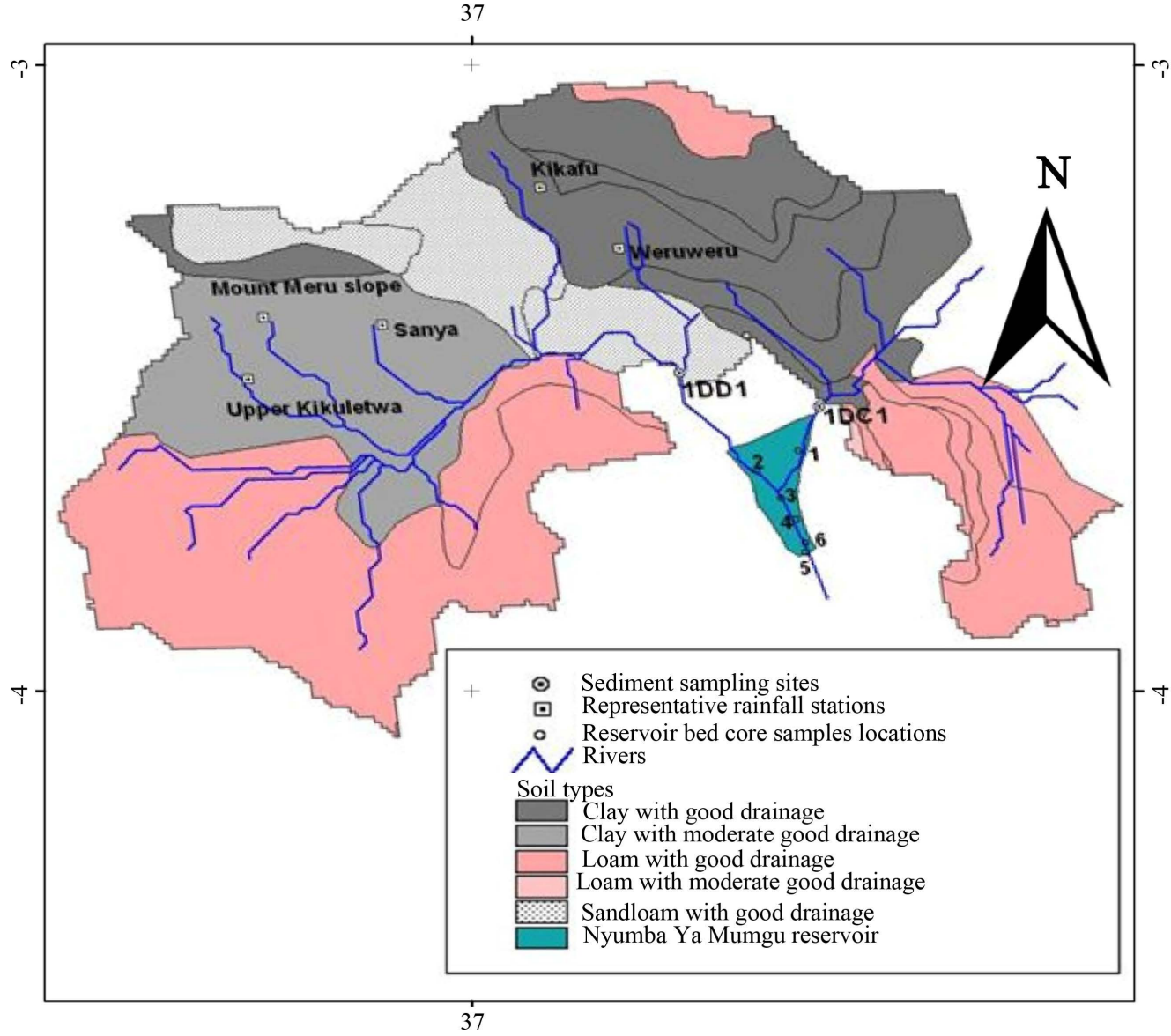

(b)

Figure 1. (a) Sediment sampling research sites in the Nyumba Ya Mungu reservoir catchment used for collecting data on sediment sources and processes identification [2]; (b) A soil map of Nyumba Ya Mungu Reservoir catchment (as adopted from [2]). 
Table 1. Soil degradation types (as adopted from [5]).

\begin{tabular}{|c|c|}
\hline Types & Soil Degradation \\
\hline \multicolumn{2}{|c|}{ Mapped units with human-induced soil degradation } \\
\hline \multirow{2}{*}{ W: Water Erosion } & Wt: Loss of topsoil \\
\hline & Wd: Terrain definition/mass movement \\
\hline \multirow{4}{*}{ C: Chemical Deterioration } & Cn: Loss of nutrients and/or organic matter \\
\hline & Cs: Salinization \\
\hline & Ca: Acidification \\
\hline & Cp: Pollution \\
\hline \multicolumn{2}{|c|}{ Mapped units without Human-Induced Soil Degradation } \\
\hline \multirow{4}{*}{ S: Stable terrain } & SN: Stable terrain under natural conditions \\
\hline & SA: Stable terrain with permanent agriculture \\
\hline & SR: Terrain stabilized by human intervention \\
\hline & SR: Terrain stabilized by human intervention \\
\hline
\end{tabular}

Table 2. Causal factors (as adopted from [5]).

\begin{tabular}{cc}
\hline Symbol & Causal Factor \\
\hline $\mathrm{f}$ & Deforestation and removal of the natural vegetation \\
$\mathrm{g}$ & Overgrazing \\
$\mathrm{a}$ & Agricultural activities \\
$\mathrm{e}$ & Overexploitation of vegetation for domestic use \\
$\mathrm{i}$ & Industrial activities \\
\hline
\end{tabular}

erosion; chemical deterioration; and physical deterioration). However, in this work only groups that are common for Nyumba Ya Mungu reservoir catchment and the region are described (Table 1).

The causative factors for soil degradation as stipulated in GLASOD are land use (socio-economic activities) related [5]. For this reason soil scientists who were involved in preparing the GLASOD map indicated what kind of physical human intervention has caused the soil to be degraded (Table 2).

To date a number of limitations on use of GLASOD map are perceived as follows: it is not appropriate for national breakdowns; it is qualitative and subjective; limited number of attributes due to cartographic restrictions; the map only indicates human-induced soil degradation; visual exaggeration; extent classes rather than percentages; complex legend-combined extent and degree (severity) for four major degradation types (water and wind erosion, physical and chemical deterioration); only "dominant" main type of degradation is shown; and degradation sub-types only shown by codes [13]. Recent studies by [1] have tried to assess how good is the GLASOD. Among other things, they found that experts who developed the GLASOD were only moderately consistent in assigning soil degradation classes to similar sites. They further reasoned that such inconsistencies were attributed to conceptualization of the degrees of degradation among experts coming from different countries.

\subsubsection{GLASOD Map Source, Retrieval, and Sediment Source Mapping}

The GLASOD map sourced from [13] which is retrievable and applicable under ArcView or ArcGIS packages was utilized to generate the GLASOD-features for the study area. The geoprocessing wizard tool under ArcView GIS version 3.2 view pull down menu was applied to intersect GLASOD map and study area sub-catchment boundary maps as input and overlay ArcView software themes. This operation cuts GLASOD map with the features from the study area sub-catchment boundary map to produce a new map (output theme) with features that have attributes data from both maps. The maps are linked to database tables which could be analysed and manipulated easily for information retrieval, sourcing or discovery. The main attributes captured in the new 
intersect map (output theme) include, but not limited to, sub-basin (sub-catchment) number, sub-basin area coverage, GLASOD polygon identity number, soil degradation type, severity class, and severity code. Both maps and tables were used in the qualitative analyses as intended based on the guidelines presented in [5] and author's expert knowledge.

\subsection{Sediment Sources Identification Using Quantitative Approaches}

Multi-approaches were adopted to identify the sediment sources and erosion processes. The methods herein are: analyses of single hydrological events as sampled from continuous sediment pumping sampler and water levels recording data logger; fingerprinting-organic matter contents and particle size distribution of the transported sediment by rivers or those deposited in the downstream reservoirs (infer the origin and processes of sediment in the catchment); mapping of hydrological variables-rainfall in spatial and temporal domain correlated to sediment transport characteristics at the outlet of the catchment; and numerical modelling. The methods are explained in detail in sections 2.3.1 through 2.3.4 below.

\subsubsection{Analyses of Single Hydrological Events}

The details on the sampling programme design and data processing are reported in [3]. This paper will only focus on the analytical methods used to prepare temporal graphs of streamflow and sediment concentrations. The temporal graphs were plotted on semilog paper with time as the independent variable on the arithmetic scale, and the hydrograph, (Q-graph) or concentration-time graph (C-graph) with $\mathrm{Q}$ or $\mathrm{C}$ on the ordinate. The rating loops method was used to explain causes of many of the resulting C-Q relationships. They were also used to indicate both the spread of the observations and the temporal variations between $\mathrm{C}$ and Q during a storm event [2].

\subsubsection{Fingerprinting Techniques}

The fingerprint techniques involved use of sediment properties as a natural tracer. Sediment origin was determined using natural properties of soil, reservoir bed substrate and suspended matter to fingerprint sediment sources. This study adopted a loss-on-ignition technique in estimating the soil organic matter content. The correlation between organic matter content and streamflow discharge was conducted and strength of correlation was determined as recommended in [14].

\subsubsection{Hydrological Variables Mapping Technique}

Correlation technique was adopted to indicate the responsiveness of sediment concentrations in rivers to the spatial rainfall intensities [2]. The variables were not expected to be linearly correlated but relative variation of correlation coefficients gave an idea of both spatial and temporal responses. Besides, a strong correlation between the variable and sediment delivery response is confirmed if the computed correlation coefficient is higher than the corresponding value from the table at $1 \%$ probability level of significance, $p$, [14]. A correlation analysis between hydrological variables was also conducted to derive an implied correlation between them and sediment supply sources. A rainfall station for instance, presents both as either a source location or driver for sediment supply to the rivers.

\subsubsection{Numerical Erosion Modelling}

A semi-distributed, physics-based watershed model, Soil and Water Assessment Tool (SWAT: [15]) was used to model spatially distributed soil loss and/or sediment yield in the gauged sub-catchments of the study area [3]. The spatial variation of simulated soil loss/sediment yield rates across the sub-catchments, Hydrologic Response Unit (HRU) was used as indication of soil degradation severity. Erosion/soil loss and sediment yield were estimated for each HRU with the Universal Soil Loss Equation [16] and Modified Universal Soil Loss Equation (MUSLE) [17], respectively. The SWAT model uses simplified stream power equation of [18] to route sediment in the channel. However, it should be noted that this study adopted the USLE soil erodibility factor typical values for tropics from [19]. Input data required to set up a SWAT model include, land use, soil type, Digital Elevation Model (DEM) and climatic data.

\subsection{Validation of GLASOD Map on Sediment Sources Mapping Performance}

Despite the fact that it was intended to validate GLASOD map with previous findings of the quantitative approach, 
in addition the map performance was verified by location-based sediment yield rates. It should be noted that the latter are limited in terms of coverage and details. A validated Pacific Southwest Inter-Agency Committee (PSIAC) model [20] was used to estimate sediment yield based on secondary data and field observations [11]. The PSIAC approach is based on a sediment yield classification scheme employing individual drainage basin characteristics (surface geology, soils, climate, runoff, topography, ground cover, land use, upland erosion, channel erosion, and sediment transport). The PSIAC model was built from readily available environmental variables sourced from Tanzania Government's ministries/agencies and public domain global spatial data. Basic data for PSIAC model factor derivation were obtained from topographic maps, geological, soil, land use, ground cover, runoff, climate (mean annual rainfall), and Normalized Difference Vegetation Index map (NDVI). The data were used to generate spatial data layers and to evaluate the sediment factors based on PSIAC concept for the sediment model determination under GIS environment. Each river characteristic was scaled based on PSIAC sediment yield factor rating sheet. All factors characterized by PSIAC model approach were described in a way of acquiring the PSIAC-Indices for each catchment. The PSIAC-Indices for the 31 dams' siltation data were obtained through preparation, classification and assignment of weights according to PSIAC model building procedures [11].

Computed Sediment yields for surveyed locations geographically matching with GLASOD map features within the study area were analyzed and reclassified percentiles to represent four (4) severity levels. The percentiles are scaled as $0 \%-25 \%$ for severity of $1 ; 25 \%-50 \%$ for severity of $2 ; 50 \%-75 \%$ for severity of 3 ; and $75 \%-100 \%$ for severity of 4 . Field data and GLASOD map severities were correlated. A Student's t-distribution table was used to confirm the strength of correlation. The correlation was considered strong if a computed $t$ value is greater than table value at $5 \%$ level of significance as recommended by [21]. Besides, coefficient of determination, $\mathrm{R}^{2}$, values greater than 0.5 were considered acceptable as suggested by other researchers [22].

\section{Results and Discussions}

\subsection{Identified Sediment Sources and Erosion Processes Based on GLASOD Map}

In this section of the paper a detailed explanation on the identified sediment sources and erosion processes based on extracted attributes from GLASOD map is provided. For this purpose, Figure 2 and Table 3 and Table 4 are

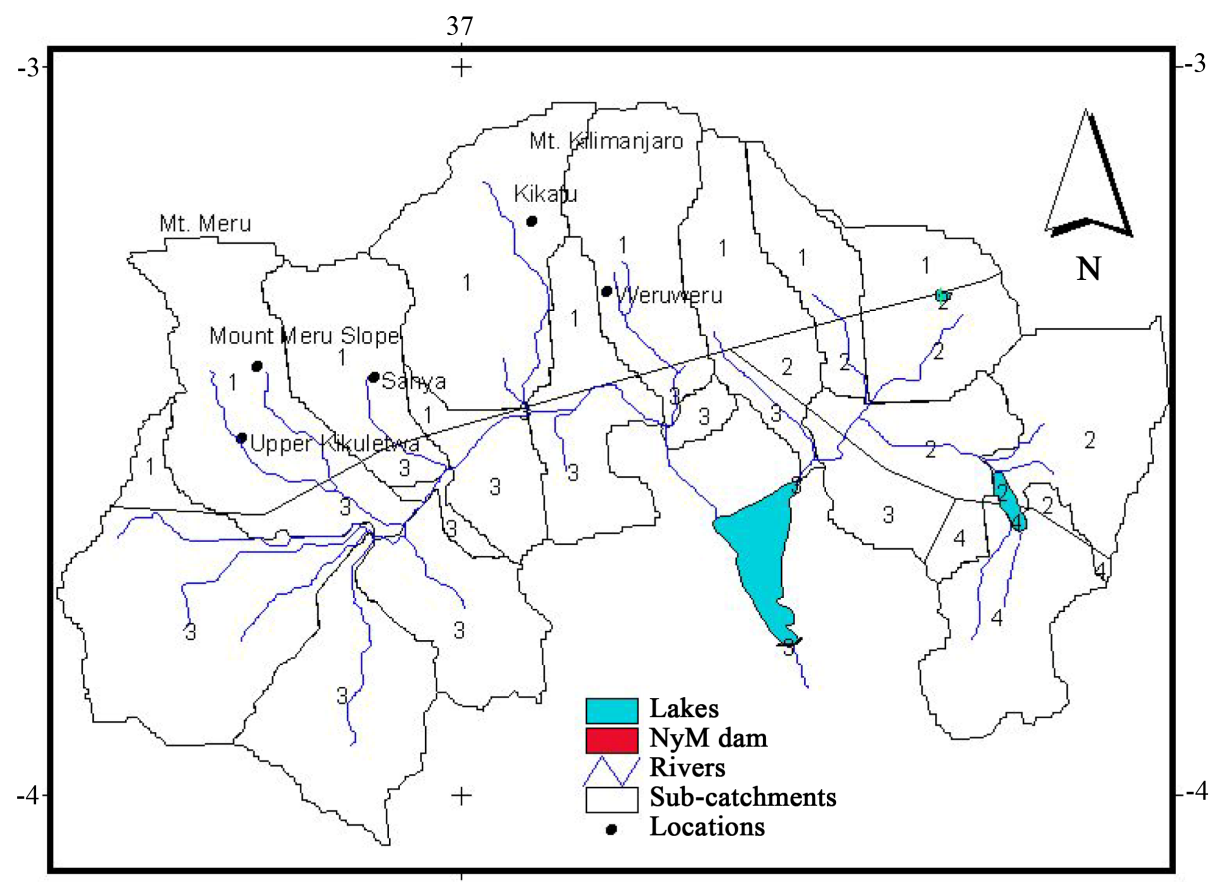

37

Figure 2. Severity classes of soil degradation in the upstream of Nyumba Ya Mungu reservoir based on GLASOD map. 
referred to Figure 2, a generated GLASOD map as described in section 2.2.2 presents degradation severity classes for all 20 subcatchments of the Nyumba Ya Mungu Reservoir catchment. You would see that there were 4 severity classes mapped in the study area. This suggests that the study area is heterogeneous, that is to say soil degradation phenomena is spatially variable. However, one could see that there is a general spatial pattern on soil degradation status. Severity classes for upstream part of mountainous catchments, along Mts. Kilimanjaro and Meru slopes, have lower severity classes than the downstream parts of respective catchments. An exception trend is observed on the eastern part of the study area, especially on the Pare Mountains (upstream of Lake Jipe), where degradation is characterised by higher severity classes. It is noteworthy that severity class of 1 dominates the study area with coverage of about 35 percent (Figure 2; Table 3 \& Table 4). Severity class of 4 with a least coverage represents only 15 percent of the area. This suggests that erosion prone areas or sources are localized within the study area.

Table 3 presents the status of soil degradation considering the type, extent, degree, rate and causative factors of degradation within physiographic units, sub-catchments, in the study area. The table shows that, with exception of 8 sub-catchments (i.e., 11, 12,13, 14, 15, 16, 17, and 19), there are two types of soil degradation recognized in each mapped unit. That is why an aggregated severity (severity class) is presented/provided as well. Where a soil degradation type 2 is nonexistent, a value of zero (0) is assigned to soil degradation characteristics. For map units with two causative factors, the sequence of appearance in the last column of Table 3 does neither indicate a sequence in importance, nor it necessarily coincide with the sequence of degradation types indicated in the table. As depicted in the table the aggregated severity is sometimes higher than severity of the individual degradation type. For some mapping units where one of the two degradation types is subordinate, the aggregated severity is one class higher than the severity of the most important type. This always occurs when the severity of the second type is significant enough to have a bearing on the overall severity [5]. The degree of degradation, relative extent of degradation and causative factors are used in combination to define the severity of soil degradation. For instance, severity code of Wt2.3.g/\#, in Table 3, sub-catchment number 1, the two letter codes (Wt) identify the type of soil degradation. This letter combination is followed by two numbers: the first number (2) refers to the degree; the second number (3) refers to the relative extent of soil degradation with overgrazing (g) as the causative factor and the severity class upgraded (\#). Wt2.3 therefore means that the degradation type "loss of topsoil through water erosion” (Wt) has a moderate degree (2) and occurs frequently (3) caused by overgrazing with severity class (\#) upgraded.

For clarity purpose, the characteristics in Table 3 are summarized and expounded in Table 4. In Table 4 soil degradation characteristics are presented for all 20 sub-catchments in the study area. Such presentation format will be useful in comparing between GLASOD and previous studies' results. For such purpose, other attributes including catchment name and area coverage are introduced. Table 4 indicates that there are two main degradation types, viz., loss of top soil through water erosion and terrain definition/mass movement through water erosion with degree of degradation varying from light to strong. With the exception of Lake Jipe sub-catchment, the downstream parts of the sub-catchment soil degradation are in the form of mass movement. It should be understood that the most common phenomena of Terrain definition/mass movement degradation type as defined on GLASOD map are rill, gully formation, riverbank destruction and landslides [5].

Loss of top soil through water erosion (sheet erosion) degradation type is found in the upstream parts of the catchment. As farming activity in the study area is practiced on the upper sub-catchments, slopes of Mts. Kilimanjaro and Meru, it is perceived that topsoil is rich in nutrients. Therefore, a relatively large amount of nutrients may be lost together with the topsoil. Such degradation type may lead to an impoverishment of the soil. In this context, on very steep slopes of Mts. Kilimanjaro and Meru, natural loss of topsoil may occur frequently. Unfortunately, this "geologic erosion" could not be indicated on the GLASOD map. Degree of degradation in the Lake Jipe sub-catchment is very strong and besides it experiences both sheet erosion and mass movement degradation types. In general the principal external dynamic agent of erosion is the hydrospheric forces of water, i.e., rainfall, runoff, and stream flows. The data from table also suggest that soil degradation is caused mainly through removal of natural vegetation and overgrazing. The latter is practised in major parts of the study area with coverage of 85 percent. The terrain in the overgrazed area could be characterized as low lands and sparsely vegetated. The two causative factors, removal of the natural vegetation and overgrazing are interrelated and have interplay role in triggering erosion. According to [5], on GLASOD map, removal of the natural vegetation is normally attributed to land reclamation activities such as farming, cattle raising, road construction, and urban development. On the other hand, the effect of overgrazing is linked to livestock trampling. Trampling may cause 
Table 3. Soil degradation characteristics for the Nyumba Ya Mungu reservoir catchment based on GLASOD map.

\begin{tabular}{|c|c|c|c|c|c|c|c|c|c|c|c|c|c|c|c|}
\hline \multirow{2}{*}{ 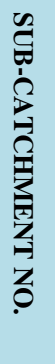 } & \multirow{2}{*}{ 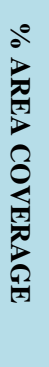 } & \multirow{2}{*}{ 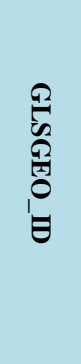 } & \multicolumn{6}{|c|}{ SOIL DEGRADATION TYPE 1} & \multicolumn{5}{|c|}{$\begin{array}{c}\text { SOIL DEGRADATION } \\
\text { TYPE } 2\end{array}$} & \multirow{2}{*}{ 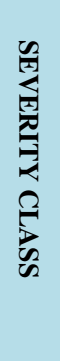 } & \multirow{2}{*}{ 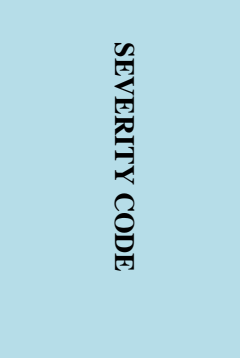 } \\
\hline & & & 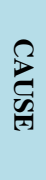 & 武 & 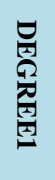 & $\begin{array}{l}\text { 㼛 } \\
\text { 四 } \\
\text { 学 }\end{array}$ & 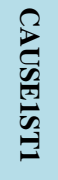 & 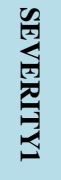 & 惫 & 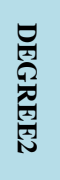 & 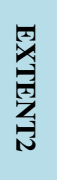 & 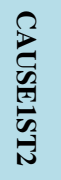 & 尔 & & \\
\hline 1 & 3 & 1616 & g & Wt & 2 & 3 & g & 3 & Wd & 3 & 1 & g & 2 & 3 & Wt2.3.g/\#Wd3.1.g/\# \\
\hline 2 & 3 & 1616 & g & Wt & 2 & 3 & g & 3 & Wd & 3 & 1 & g & 2 & 3 & Wt2.3.g/\#Wd3.1.g/\# \\
\hline \multirow[t]{2}{*}{3} & 3 & 1568 & g & Wt & 1 & 2 & g & 1 & Wd & 1 & 2 & g & 1 & 1 & Wt1.2.g/\#Wd1.2.g/\# \\
\hline & 3 & 1616 & g & Wt & 2 & 3 & g & 3 & Wd & 3 & 1 & g & 2 & 3 & Wt2.3.g/\#Wd3.1.g/\# \\
\hline 4 & 3 & 1616 & g & $\mathrm{Wt}$ & 2 & 3 & g & 3 & Wd & 3 & 1 & g & 2 & 3 & Wt2.3.g/\#Wd3.1.g/\# \\
\hline \multirow[t]{2}{*}{5} & 3 & 1568 & g & Wt & 1 & 2 & g & 1 & Wd & 1 & 2 & g & 1 & 1 & Wt1.2.g/\#Wd1.2.g/\# \\
\hline & 3 & 1616 & g & Wt & 2 & 3 & g & 3 & Wd & 3 & 1 & g & 2 & 3 & Wt2.3.g/\#Wd3.1.g/\# \\
\hline \multirow[t]{2}{*}{6} & 3 & 1568 & g & Wt & 1 & 2 & g & 1 & Wd & 1 & 2 & g & 1 & 1 & Wt1.2.g/\#Wd1.2.g/\# \\
\hline & 3 & 1616 & g & $\mathrm{Wt}$ & 2 & 3 & g & 3 & Wd & 3 & 1 & g & 2 & 3 & Wt2.3.g/\#Wd3.1.g/\# \\
\hline \multirow[t]{2}{*}{7} & 3 & 1568 & g & $\mathrm{Wt}$ & 1 & 2 & g & 1 & Wd & 1 & 2 & g & 1 & 1 & Wt1.2.g/\#Wd1.2.g/\# \\
\hline & 3 & 1616 & g & Wt & 2 & 3 & g & 3 & Wd & 3 & 1 & g & 2 & 3 & Wt2.3.g/\#Wd3.1.g/\# \\
\hline \multirow[t]{2}{*}{8} & 3 & 1568 & g & Wt & 1 & 2 & g & 1 & Wd & 1 & 2 & g & 1 & 1 & Wt1.2.g/\#Wd1.2.g/\# \\
\hline & 3 & 1616 & g & Wt & 2 & 3 & g & 3 & Wd & 3 & 1 & g & 2 & 3 & Wt2.3.g/\#Wd3.1.g/\# \\
\hline \multirow[t]{2}{*}{9} & 3 & 1568 & g & Wt & 1 & 2 & g & 1 & Wd & 1 & 2 & g & 1 & 1 & Wt1.2.g/\#Wd1.2.g/\# \\
\hline & 3 & 1616 & g & $\mathrm{Wt}$ & 2 & 3 & g & 3 & Wd & 3 & 1 & g & 2 & 3 & Wt2.3.g/\#Wd3.1.g/\# \\
\hline 10 & 3 & 1616 & g & $\mathrm{Wt}$ & 2 & 3 & g & 3 & Wd & 3 & 1 & g & 2 & 3 & Wt2.3.g/\#Wd3.1.g/\# \\
\hline \multirow[t]{3}{*}{11} & 2 & 1555 & g & Wt & 1 & 4 & g & 2 & & 0 & 0 & & 0 & 2 & Wt1.4.g/\#./\# \\
\hline & 3 & 1568 & g & Wt & 1 & 2 & g & 1 & Wd & 1 & 2 & g & 1 & 1 & Wt1.2.g/\#Wd1.2.g/\# \\
\hline & 3 & 1616 & g & $\mathrm{Wt}$ & 2 & 3 & g & 3 & Wd & 3 & 1 & g & 2 & 3 & Wt2.3.g/\#Wd3.1.g/\# \\
\hline \multirow[t]{3}{*}{12} & 2 & 1555 & g & $\mathrm{Wt}$ & 1 & 4 & g & 2 & & 0 & 0 & & 0 & 2 & Wt1.4.g/\#. \\
\hline & 3 & 1616 & g & $\mathrm{Wt}$ & 2 & 3 & g & 3 & Wd & 3 & 1 & g & 2 & 3 & Wt2.3.g/\#Wd3.1.g/\# \\
\hline & 1 & 1621 & $\mathrm{f}$ & Wt & 3 & 4 & $\mathrm{f}$ & 4 & Wd & 3 & 2 & $\mathrm{f}$ & 3 & 4 & Wt3.4.f/\#Wd3.2.f/\# \\
\hline \multirow[t]{3}{*}{13} & 2 & 1555 & g & Wt & 1 & 4 & g & 2 & & 0 & 0 & & 0 & 2 & Wt1.4.g/\#./\# \\
\hline & 2 & 1555 & g & Wt & 1 & 4 & g & 2 & & 0 & 0 & & 0 & 2 & Wt1.4.g/\#./\# \\
\hline & 1 & 1621 & $\mathrm{f}$ & Wt & 3 & 4 & $\mathrm{f}$ & 4 & Wd & 3 & 2 & $\mathrm{f}$ & 3 & 4 & Wt3.4.f/\#Wd3.2.f/\# \\
\hline \multirow[t]{2}{*}{14} & 2 & 1555 & g & Wt & 1 & 4 & g & 2 & & 0 & 0 & & 0 & 2 & Wt1.4.g/\#./\# \\
\hline & 1 & 1621 & $\mathrm{f}$ & Wt & 3 & 4 & $\mathrm{f}$ & 4 & Wd & 3 & 2 & $\mathrm{f}$ & 3 & 4 & Wt3.4.f/\#Wd3.2.f/\# \\
\hline \multirow[t]{3}{*}{15} & 2 & 1555 & g & Wt & 1 & 4 & g & 2 & & 0 & 0 & & 0 & 2 & Wt1.4.g/\#.\#\# \\
\hline & 1 & 1621 & $\mathrm{f}$ & $\mathrm{Wt}$ & 3 & 4 & $\mathrm{f}$ & 4 & Wd & 3 & 2 & $\mathrm{f}$ & 3 & 4 & Wt3.4.f/\#Wd3.2.f/\# \\
\hline & 1 & 1621 & $\mathrm{f}$ & Wt & 3 & 4 & $\mathrm{f}$ & 4 & Wd & 3 & 2 & $\mathrm{f}$ & 3 & 4 & Wt3.4.f/\#Wd3.2.f/\# \\
\hline \multirow[t]{2}{*}{16} & 2 & 1555 & g & $\mathrm{Wt}$ & 1 & 4 & g & 2 & & 0 & 0 & & 0 & 2 & Wt1.4.g/\#./\# \\
\hline & 3 & 1568 & g & $\mathrm{Wt}$ & 1 & 2 & g & 1 & Wd & 1 & 2 & g & 1 & 1 & Wt1.2.g/\#Wd1.2.g/\# \\
\hline \multirow[t]{2}{*}{17} & 2 & 1555 & g & Wt & 1 & 4 & g & 2 & & 0 & 0 & & 0 & 2 & Wt1.4.g/\#./\# \\
\hline & 3 & 1568 & g & Wt & 1 & 2 & g & 1 & Wd & 1 & 2 & g & 1 & 1 & Wt1.2.g/\#Wd1.2.g/\# \\
\hline \multirow[t]{2}{*}{18} & 3 & 1568 & g & $\mathrm{Wt}$ & 1 & 2 & g & 1 & Wd & 1 & 2 & g & 1 & 1 & Wt1.2.g/\#Wd1.2.g/\# \\
\hline & 3 & 1616 & g & Wt & 2 & 3 & g & 3 & Wd & 3 & 1 & g & 2 & 3 & Wt2.3.g/\#Wd3.1.g/\# \\
\hline 19 & 2 & 1555 & g & Wt & 1 & 4 & g & 2 & & 0 & 0 & & 0 & 2 & Wt1.4.g/\#./\# \\
\hline & 3 & 1568 & g & Wt & 1 & 2 & g & 1 & Wd & 1 & 2 & g & 1 & 1 & Wt1.2.g/\#Wd1.2.g/\# \\
\hline 20 & 3 & 1616 & $\mathrm{~g}$ & Wt & 2 & 3 & $\mathrm{~g}$ & 3 & Wd & 3 & 1 & g & 2 & 3 & Wt2.3.g/\#Wd3.1.g/\# \\
\hline
\end{tabular}


Table 4. Severity of soil erosion and causative factors (sediment sources) in the Nyumba Ya Mungu reservoir catchment.

\begin{tabular}{|c|c|c|c|c|c|c|c|c|}
\hline SN & $\begin{array}{c}\text { Sub-catchment } \\
\text { Name }\end{array}$ & $\begin{array}{l}\text { Severity } \\
\text { Code }\end{array}$ & $\begin{array}{c}\text { Degradation } \\
\text { type }\end{array}$ & $\begin{array}{c}\text { Degree of } \\
\text { degradation }\end{array}$ & $\begin{array}{c}\text { Relative } \\
\text { extent of } \\
\text { degradation }\end{array}$ & $\begin{array}{l}\text { Causative } \\
\text { factors }\end{array}$ & $\begin{array}{l}\text { Severity } \\
\text { Class }\end{array}$ & $\begin{array}{c}\text { Area } \\
\text { coverage } \\
(\%)\end{array}$ \\
\hline \multirow[b]{2}{*}{1} & \multirow{2}{*}{$\begin{array}{c}\text { Upper } \\
\text { catchments of } \\
\text { Lake Jipe }\end{array}$} & Wt3.4.f & $\begin{array}{l}\text { Loss of top soil } \\
\text { through water } \\
\text { erosion }\end{array}$ & Strong & Very frequent & $\begin{array}{l}\text { Removal of } \\
\text { the natural } \\
\text { vegetation }\end{array}$ & 4 & \multirow[b]{2}{*}{15} \\
\hline & & Wd3.2.f & $\begin{array}{c}\text { Terrain } \\
\text { definition/mass } \\
\text { movement through } \\
\text { water erosion }\end{array}$ & Strong & Common & $\begin{array}{l}\text { Removal of } \\
\text { the natural } \\
\text { vegetation }\end{array}$ & 4 & \\
\hline \multirow[b]{2}{*}{2} & $\begin{array}{l}\text { Kisangiro } \\
\text { catchment; } \\
\text { downstream of } \\
\text { Ruvu river, } \\
\text { Upper }\end{array}$ & Wt2.3.g & $\begin{array}{l}\text { Loss of top soil } \\
\text { through water } \\
\text { erosion }\end{array}$ & Moderate & Frequent & Overgrazing & 3 & \multirow[b]{2}{*}{24} \\
\hline & $\begin{array}{c}\text { Kikuletwa } \\
\text { (maasai steppe), } \\
\text { Sanya, Kikafu, } \\
\text { Weruweru, } \\
\text { Karanga } \\
\text { catchments }\end{array}$ & Wd3.1.g & $\begin{array}{c}\text { Terrain } \\
\text { definition/mass } \\
\text { movement through } \\
\text { water erosion }\end{array}$ & Strong & Light & Overgrazing & 3 & \\
\hline 3 & $\begin{array}{l}\text { Downstream of } \\
\text { Rau, Mue, } \\
\text { Himo } \\
\text { catchments; } \\
\text { Lake Chala } \\
\text { catchment; and } \\
\text { eastern part of } \\
\text { Lake Jipe } \\
\text { Catchment }\end{array}$ & Wt1.4g & $\begin{array}{l}\text { Loss of top soil } \\
\text { through water } \\
\text { erosion }\end{array}$ & Light & Very frequent & Overgrazing & 2 & 26 \\
\hline \multirow[b]{2}{*}{4} & $\begin{array}{l}\text { Mount Meru } \\
\text { slopes } \\
\text { catchment; }\end{array}$ & Wt1.2.g & $\begin{array}{l}\text { Loss of top soil } \\
\text { through water } \\
\text { erosion }\end{array}$ & Light & Common & Overgrazing & 1 & \multirow[b]{2}{*}{35} \\
\hline & $\begin{array}{c}\text { Upstream of } \\
\text { Upper } \\
\text { Kikuletwa, } \\
\text { Sanya, Kikafu, } \\
\text { Weruweru, } \\
\text { Himo, Mue, \& } \\
\text { Rau catchments }\end{array}$ & Wd1.2.g & $\begin{array}{c}\text { Terrain } \\
\text { definition/mass } \\
\text { movement through } \\
\text { water erosion }\end{array}$ & Light & Common & Overgrazing & 1 & \\
\hline
\end{tabular}

compaction of the soil. The phenomenon of compaction and/or crusting may cause a decrease in infiltration capacity of the soil, and leading to accelerated run-off and soil erosion. Directly, overgrazing usually leads to a decrease of the soil vegetative cover. As a result the water and wind erosion potential on bare soil/land increases. In general this result suggests that poor farming and overgrazing practices are the main causes of erosion in the study area. Therefore sediment sources are areas where the main socio-economic activities are farming and/or cattle grazing. Based on the foregoing discussions, notably, sheet erosion occurs across the study area with varying relative extent from common to very frequent. Other types of erosion such as gullying and landslides are localized.

\subsection{Evaluated GLASOD Map Performance}

As presented in Table 5 and noted earlier in this paper previous research in the study area identified location based sediment sources using quantitative approaches. It was ascertained through fingerprinting techniques that these sources are located in upland catchment, in the agricultural fields in the headwater regions, i.e., runoff generating catchments located on the foot slopes of Mts. Kilimanjaro and Meru. These are zones of maximum 
Table 5. Comparison between qualitative and quantitative approach performances.

\begin{tabular}{|c|c|c|c|c|c|}
\hline \multirow{2}{*}{\multicolumn{2}{|c|}{$\begin{array}{l}\text { Qualitative approach } \\
\text { GLASOD Map } \\
\text { (This study) }\end{array}$}} & \multicolumn{4}{|c|}{ Quantitative approach } \\
\hline & & & $\begin{array}{l}\text { Modelling } \\
{[10,3]}\end{array}$ & & $\begin{array}{c}\text { mpling programme (indirect methods } \\
\text { and fingerprinting techniques } \\
{[10,3]}\end{array}$ \\
\hline 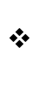 & $\begin{array}{l}\text { Regional (GLASOD map unit) based } \\
\text { sediment sources. }\end{array}$ & $*$ & $\begin{array}{l}\text { Subcatchment wise } \\
\text { sediment sources } \\
\text { identified }\end{array}$ & 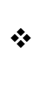 & $\begin{array}{l}\text { Location specific based } \\
\text { sediment sources identified. }\end{array}$ \\
\hline 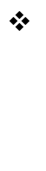 & $\begin{array}{l}\text { Sheet erosion (top soil removal) dominates in } \\
\text { 1DD1 (Kikuletwa) sub-catchment. Not detailed } \\
\text { enough to indicate sediment contents and } \\
\text { characteristics (organic matter and particle } \\
\text { size distribution) }\end{array}$ & $\star$ & $\begin{array}{l}\text { Sheet erosion } \\
\text { dominates in 1DD1 } \\
\text { (Kikuletwa) } \\
\text { sub-catchment }\end{array}$ & 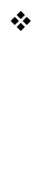 & $\begin{array}{l}\text { Top layer A-horizon or Sheet erosion } \\
\text { dominates in 1DD1 (Kikuletwa) } \\
\text { sub-catchment. High organic matter } \\
\text { content and fine-grained characterize } \\
\text { the sediment contents delivered at outlet }\end{array}$ \\
\hline 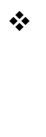 & $\begin{array}{l}\text { Mass movement depicted, however, it does not } \\
\text { tell which type of mass movement } \\
\text { (rill, gully formation, riverbank } \\
\text { destruction, or landslides) }\end{array}$ & $*$ & $\begin{array}{l}\text { Gully erosion } \\
\text { is insignificant }\end{array}$ & 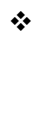 & $\begin{array}{l}\text { Insignificant gully erosion process in } \\
\text { 1DD1 sub-catchment. Based on aerial } \\
\text { photos, few and localized growing } \\
\text { gullies in some mountain foot slopes }\end{array}$ \\
\hline 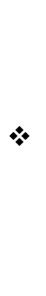 & $\begin{array}{l}\text { Indirectly captured as terrain } \\
\text { definition or mass movement }\end{array}$ & $\star$ & $\begin{array}{l}\text { Within channel } \\
\text { sediment sources }\end{array}$ & 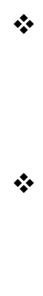 & $\begin{array}{l}\text { Lesser extent within channel sediment } \\
\text { sources in 1DD1 sub-catchment. } \\
\text { Sediment concentrations delivery } \\
\text { at outlet though low are sustained even } \\
\text { during low flow or dry season } \\
\text { Bank erosion in Ruvu River as } \\
\text { monitored at 1DC1 gauging station. } \\
\text { Sometimes sediment peaks } \\
\text { lead the flood peaks. }\end{array}$ \\
\hline
\end{tabular}

biological activity-the topsoil (i.e., A-horizon) or plow layer in slopes of Mounts Kilimanjaro and Meru slopes. Based on Particle Size Distribution (PSD) analysis and mapping of catchment soil types, the soils in these regions are characterized as clays (Figure 1(b)). Sheet erosion was perceived as dominant erosion process in 1DD1 (Kikuletwa) catchment. Besides, sediment sources are headwater regions where both farming and animal keeping activities are practised. Therefore, within channel sources are comparatively insignificant. Cultivation activities in the foot slopes of Mounts Kilimanjaro and Meru are the major sediment delivery sources to the outlet of the catchment. The studies revealed further that Weruweru, Kikafu and Mount Meru foot slopes' subcatchments are major contributors of sediment from sheet erosion.

Through analysis of field based data and modelling exercise sheet erosion was identified as a major erosion process in the upland catchment. From aerial photos interpretation and modelling exercises it was found that growing gully features are few and localized in some mountain foot slopes of the catchments [3]. They contribute only $1.6 \%$ of the catchment sediment yield. It was ascertained that gullies are localized erosion features in the catchment and their spatial distribution is influenced by natural runoff generating factors and to a lesser extent the land use. It was therefore concluded that gully erosion is insignificant erosion process. Based on calibrated and validated numerical model frameworks, within channel sediment sources contribute about $3.2 \%$ of the Kikuletwa sub-catchment sediment yield. Rating loops analyses indicate that counter-clockwise hysteresis dominates over clockwise loops from analyzed single hydrological events especially during the wet season suggests that far sources from the sampling site at 1DD1 gauging station (Figure 1(a)) are responsible as major sediment supply in the catchment. Therefore, it was affirmed that channel sediment sources are insignificant, especially for Kikulewa River. However, there are evidences of channel bank erosion and bed erosion sources in Ruvu River in IDC1 sub-catchment. The sediment flow data in Ruvu River demonstrated higher erratic scatter between sediment loads and flow discharge than for Kikuletwa River. Such patterns suggested that Kikuletwa sub-catchment is dominated by fewer erosion processes than Ruvu sub-catchment (IDC1).

Generally, in the previous studies, 1DD1 (Kikuletwa) sub-catchment was identified as the major sediment source to downstream Nyumba Ya Mungu (NYM) reservoir with about 97.5\% contribution of the total sediment. 1DC1 (Ruvu) sub-catchment contributes only 2.5\% of the total inflowing sediment load to the reservoir. It was also found that most of the sediments eroded from hill slopes don't find their way to the NYM reservoir because 
they are deposited in the plains (swamps, lakes, flood plains, low lands) which were estimated to cover about 73\% of the catchment area. As observed from the field visits Lake Jipe is one of the sediment depository sites. Previous study therefore called upon a further research work that would study the dynamics of the sediment transport of the deposited sediments in the lakes and floodplains. The quest was to know what will happen to the sediment deposits after 100 years from now.

It is noteworthy that previous studies did not map sediment sources within Lake Jipe sub catchments as it has been attempted by this study. Rather, the influence of the Lake Jipe and its entire catchment to the sediment transport was understood through analyses of hydrograph and sediment-graph analyses at 1DC1 gauging station, downstream outlet of Ruvu sub-catchment [2]. It was revealed for instance that clear sediment runoff waters from Lake Jipe located upstream sustain the flow with little or no sediment supply at 1DC1 gauging station. Notwithstanding, both the quantitative and qualitative approaches (Table 5) and recent field visits' observations (Table 6) indicate that in Ruvu River sub-catchment there are multi-erosion processes, viz., sheet, gullying, and bank and channel erosion. Further, GLASOD map based on severity class has indicated that Ruvu catchment including Lake Jipe subcatchments is strongly degraded. Probably this finding explains why sediment deposits in Lake Jipe are evident.

Further validation could be supported by recent field visits' observations as presented in Table 6. The main sources of sediment in the study area are small scale agricultural activities and lower channel occasional active banks in meanders. Agriculture is practiced on slopes on upper catchment without buffering zones. There are also isolated bank cultivations. In the study area, the sediment sources are small scale agriculture (headwater areas), grazing lands (Maasai Steppe), gullies (Themi River), and stream channels (bed and banks degradation).

Further analysis indicates that the present degree of soil degradation could be characterized mainly as light, moderate and/or strong. For light degree means that the terrain has somewhat reduced agricultural suitability, but is suitable for use in local farming systems. Restoration to full productivity is possible by modifications of the management systems. In case of moderate degree, the terrain has greatly reduced agricultural productivity but is still suitable for use in local farming systems. Major improvements are required to restore productivity. For strong degree of soil degradation implies that the terrain is non reclaimable at farm level. Major engineering works are required for terrain restoration. Based on these discussions, one would learn that in major part of the study area the soil degradation is severe to an extent that major improvements are required to restore productivity. In some few localized spots soil degradation is very serious such that the terrain is non reclaimable at farm level. In such localities major engineering works are required for terrain restoration.

In general there are evidences of human induced channel erosion as a result of bank cultivation and channel modification for water supply/irrigation activities (Table 6). Upland contribution was evidenced by presence of sand bars on middle and lower reaches of Ruvu River. Channel erosion processes include aggregation and degradation-incision/widening (bank failure) on middle and lower reach of the catchment. Most human activities (small scale mining and agriculture) are induced driving factors for degradation processes.

\subsection{GLASOD Severity Validation Based on Field Observations' Data in the Study Area}

It was found that field data and GLASOD map severity correlate strongly with a coefficient of determination, $\mathrm{R}^{2}$, of 0.7 or coefficient of correlation, $r$, of 0.84 (Table 7). Besides, since the computed $t_{\text {computed }}$ of 3.40 is greater than the corresponding table value, $\mathrm{t}_{0.05}($ table) of 2.57 at $5 \%$ level of significance then the correlation was confirmed to be strong.

Independent analyses indicate that paired information, field based data versus GLASOD, for upper catchments or upland locations are strongly correlated than lower reaches. For instance, whereas field visits' observations revealed that some lower river reaches channel bed sand bars, collapsing banks or extensive floodplains act as sediment sources GLASOD map indicated negligible severity.

\section{Conclusions and Recommendations}

In the current study, sediment sources mapped from qualitative (GLASOD) and quantitative approaches plus supplement field visit observations are compared. The preliminary results suggest that the paired information on sediment sources, field based data versus GLASOD, for upper catchments or upland locations is more strongly correlated than lower reaches. For instance, whereas field visit observations revealed that some lower river reaches channel bed sand bars, collapsing banks or extensive floodplains act as sediment sources; GLASOD map 
Table 6. Assessment of river channel and evolution in the Pangani Basin.

\begin{tabular}{|c|c|c|c|c|c|c|c|c|c|}
\hline \multirow{2}{*}{$\mathbf{S} / \mathbf{N}$} & \multirow{2}{*}{$\begin{array}{c}\text { Field } \\
\text { Observation } \\
\text { Sites }\end{array}$} & \multicolumn{2}{|c|}{ Location: Zone 36} & \multicolumn{3}{|c|}{ Assessment of River Channels } & \multicolumn{3}{|c|}{$\begin{array}{l}\text { Channel Evolution and } \\
\text { Hydrologic Variations }\end{array}$} \\
\hline & & $\begin{array}{l}\text { Northing } \\
\text { (m) }\end{array}$ & $\begin{array}{c}\text { Easting } \\
\text { (m) }\end{array}$ & $\begin{array}{l}\text { Upland } \\
\text { Contribution }\end{array}$ & $\begin{array}{l}\text { Channel } \\
\text { Contribution }\end{array}$ & $\begin{array}{l}\text { Future } \\
\text { Supply }\end{array}$ & $\begin{array}{l}\text { Alluvial } \\
\text { Stratigraphy }\end{array}$ & Process & Landuse \\
\hline 1 & $\begin{array}{l}\text { ID8C-Pangani-D } \\
\text { ownstream of } \\
\text { NYM Dam }\end{array}$ & $9,575,635$ & 328,840 & $\begin{array}{l}\text { No apparent } \\
\text { channel } \\
\text { modification }\end{array}$ & $\begin{array}{l}\text { Occasional } \\
\text { bank } \\
\text { erosion-active } \\
\text { cut bank in } \\
\text { meander }\end{array}$ & $\begin{array}{l}\text { Thick v } \\
\text { alley } \\
\text { bottom } \\
\text { deposits }\end{array}$ & $\begin{array}{c}\text { Older } \\
\text { channel } \\
\text { alluvium }\end{array}$ & $\begin{array}{l}\text { Incision } \\
\text { and } \\
\text { sediment } \\
\text { transport }\end{array}$ & $\begin{array}{c}<50 \% \text { crops, } \\
\text { but poorly } \\
\text { maintained }\end{array}$ \\
\hline 2 & $\begin{array}{l}\text { Ruvu at } \\
\text { Handeni }\end{array}$ & $9,604,007$ & 329,750 & $\begin{array}{l}\text { Buried } \\
\text { vegetation }\end{array}$ & $\begin{array}{c}\text { Active cut } \\
\text { banks, long } \\
\text { extent exposed } \\
\text { to water }\end{array}$ & $\begin{array}{l}\text { Thick } \\
\text { valley } \\
\text { bottom } \\
\text { deposits } \\
\text { Active } \\
\text { meanders }\end{array}$ & $\begin{array}{c}\text { Older } \\
\text { channel } \\
\text { alluvium }\end{array}$ & $\begin{array}{l}\text { Incision } \\
\text { and } \\
\text { sediment } \\
\text { transport }\end{array}$ & $\begin{array}{c}<50 \% \text { crops, } \\
\text { but poorly } \\
\text { maintained }\end{array}$ \\
\hline 3 & $\begin{array}{l}\text { Ruvu at } \\
\text { Tingatinga } \\
\text { Gauging } \\
\text { Station }\end{array}$ & Nil & Nil & $\begin{array}{l}\text { Channel } \\
\text { aggradation } \\
\text { Braiding } \\
\text { Buried } \\
\text { vegetation }\end{array}$ & $\begin{array}{c}\text { Active cut } \\
\text { banks, long } \\
\text { extent exposed } \\
\text { to water }\end{array}$ & $\begin{array}{l}\text { Thick } \\
\text { valley } \\
\text { bottom } \\
\text { deposits } \\
\text { active } \\
\text { meanders }\end{array}$ & $\begin{array}{l}\text { Basal and } \\
\text { intermediate } \\
\text { units }\end{array}$ & Widening & $\begin{array}{c}<50 \% \text { crops, } \\
\text { but poorly } \\
\text { maintained }\end{array}$ \\
\hline 4 & Lake Jipe & & & $\begin{array}{l}\text { Channel } \\
\text { aggradation }\end{array}$ & $\begin{array}{l}\text { Pronounced } \\
\text { “U” shape, } \\
\text { enlarging } \\
\text { channel }\end{array}$ & \multicolumn{3}{|c|}{$\begin{array}{l}\text { Thick valley bottom deposits } \\
\text { Wide flat plain }\end{array}$} & $\begin{array}{c}<50 \% \text { crops, } \\
\text { but poorly } \\
\text { maintained }\end{array}$ \\
\hline 5 & $\begin{array}{c}\text { Kikuletwa } \\
\text { river at } \\
\text { Wohogachini } \\
\text {-Downstream of } \\
\text { Karangai-IDD55 }\end{array}$ & $9,606,810$ & 274,012 & $\begin{array}{c}\text { Mid } \\
\text { channel bars }\end{array}$ & $\begin{array}{c}\text { Active cut } \\
\text { banks, long } \\
\text { extent exposed } \\
\text { to water } \\
\text { Pronounced “U” } \\
\text { shape, } \\
\text { enlarging } \\
\text { channel }\end{array}$ & $\begin{array}{l}\text { Narrow } \\
\text { or no } \\
\text { flood } \\
\text { plains }\end{array}$ & $\begin{array}{c}\text { Older } \\
\text { channel } \\
\text { alluvium }\end{array}$ & $\begin{array}{l}\text { Incision } \\
\text { and } \\
\text { sediment } \\
\text { transport }\end{array}$ & $\begin{array}{c}<50 \% \text { crops, } \\
\text { but poorly } \\
\text { maintained }\end{array}$ \\
\hline 6 & $\begin{array}{l}\text { Kikuletwa river } \\
\text { at } \\
\text { Karangai-IDD55 }\end{array}$ & $9,618,937$ & 261,953 & $\begin{array}{l}\text { No apparent } \\
\text { channel } \\
\text { modification }\end{array}$ & $\begin{array}{l}\text { Occasional } \\
\text { bank } \\
\text { erosion-active } \\
\text { cut bank in } \\
\text { meander }\end{array}$ & $\begin{array}{l}\text { Normal } \\
\text { channel } \\
\text { activity }\end{array}$ & $\begin{array}{c}\text { Older } \\
\text { channel } \\
\text { alluvium }\end{array}$ & $\begin{array}{l}\text { Incision } \\
\text { and } \\
\text { sediment } \\
\text { transport }\end{array}$ & $\begin{array}{c}<50 \% \text { crops, } \\
\text { but poorly } \\
\text { maintained }\end{array}$ \\
\hline 7 & $\begin{array}{c}\text { Themi River, } \\
\text { Tributary of } \\
\text { Upper } \\
\text { Kikuletwa } \\
\text { River }\end{array}$ & $9,612,478$ & 252,208 & $\begin{array}{l}\text { Braiding } \\
\text { Buried } \\
\text { vegetation }\end{array}$ & $\begin{array}{l}\text { Active cut banks, } \\
\text { long extent } \\
\text { exposed to water }\end{array}$ & $\begin{array}{l}\text { Narrow } \\
\text { or no } \\
\text { flood } \\
\text { plains }\end{array}$ & $\begin{array}{l}\text { Older } \\
\text { channel } \\
\text { alluvium }\end{array}$ & $\begin{array}{l}\text { Incision } \\
\text { and } \\
\text { sediment } \\
\text { transport }\end{array}$ & $\begin{array}{c}<50 \% \text { crops, } \\
\text { but poorly } \\
\text { maintained }\end{array}$ \\
\hline 8 & Duluti Lake & $9,626,051$ & 254,644 & $\begin{array}{l}\text { No apparent } \\
\text { channel } \\
\text { modification }\end{array}$ & $\begin{array}{l}\text { Protected or } \\
\text { vegetated banks }\end{array}$ & Narrow or & to flood plains (C & rater Lake) & $\begin{array}{c}\text { No } \\
\text { cultivation }\end{array}$ \\
\hline 9 & Lake Chala & $9,634,339$ & 354,223 & $\begin{array}{l}\text { No apparent } \\
\text { signs of } \\
\text { erosion }\end{array}$ & $\begin{array}{l}\text { Lake in massive } \\
\text { rock, large } \\
\text { boulders or } \\
\text { well vegetated }\end{array}$ & & Crater lake & & $\begin{array}{c}\text { No } \\
\text { cultivation }\end{array}$ \\
\hline
\end{tabular}

indicated negligible severity. Besides, GLASOD map does not capture erosion processes dynamics compared to comprehensive sediment sampling programme. Notwithstanding, the GLASOD gave consistent results in upland sub-catchments (i.e., Mt. Meru slopes, Kikafu, Weruweru, Rau, Mue and Himo) and could as well map sediment sources in ungauged catchments.

The soil degradation map is far from capturing all processes of soil degradation. It should be reiterated that 
Table 7. GLASOD severity validation based on field observations’ data.

\begin{tabular}{|c|c|c|}
\hline Statistics & GLASOD & Field data \\
\hline No. of field observation sites & 7 & 7 \\
\hline Average & 2.4 & 2.3 \\
\hline Standard error & 0.4 & 0.4 \\
\hline Standard deviation & 1.1 & 1.1 \\
\hline Sample variance & 1.3 & 1.2 \\
\hline Minimum & 1.0 & 1.0 \\
\hline Maximum & 4.0 & 4.0 \\
\hline Sum & 17 & 16 \\
\hline Confidence level (95\%) & 1.05 & 1.03 \\
\hline $\mathrm{R}^{2}$ (Coefficient of Determination) & \multicolumn{2}{|c|}{07} \\
\hline Adjusted $\mathrm{R}^{2}$ & \multicolumn{2}{|c|}{0.6} \\
\hline $\mathrm{t}_{0.05}($ table $)$ & \multicolumn{2}{|c|}{2.571} \\
\hline $\mathrm{t}_{\text {computed }}$ & \multicolumn{2}{|c|}{3.416} \\
\hline
\end{tabular}

some aspects of soil degradation are not represented on the map, either because these aspects appeared to be of only minor importance, or because during preparation of the map the information was not available to required detail. The study has emphasized the fact that the soil degradation map (GLASOD) is satisfactory to depict large regional differences in soil degradation but is not capable of explaining local degradation problems. However, it might be useful for sediment sources/processes scoping studies in the study area. Besides, it could be relied upon for general planning purposes. Based on this study, it is therefore recommended to complement the GLASOD map with field based data for detail study initiatives.

\section{Acknowledgements}

This work is part of the outputs of consultancy service in which the Author as Sedimentologist in a multidisplinary team charged by Ministry of Water with the responsibility of preparing an integrated Water Resources management and development plans for 3 basins in Tanzania including Pangani Basin. I also appreciate the assistance rendered by Mr. Mdee, O. J., Assistant Lecturer, at the University of Dodoma, Tanzania in carrying out some geospatial data analysis. The paper was critically reviewed by Prof. McClain, M.; Dr. Kahimba, F. C.; and Dr. G. Lugomela, G. of UNESCO-IHE, the Netherlands; Sokoine University of Agriculture, Tanzania; and Ministry of Water, United Republic of Tanzania, respectively.

\section{References}

[1] Sonneveld, B.G.J.S. and Dent, D.L. (2009) How Good Is GLASOD? Journal of Environmental Management, 90, 274283. http://dx.doi.org/10.1016/j.jenvman.2007.09.008

[2] Ndomba, P.M., Mtalo, F. and Killingtveit, A. (2007) A Proposed Approach of Sediment Sources and Erosion Processes Identification at Large Catchments. Journal of Urban and Environmental Engineering, 1, 79-86. http://dx.doi.org/10.4090/juee.2007.v1n2.079086

[3] Ndomba, P.M. (2010). Modeling of Sedimentation Upstream of Nyumba ya Mungu Reservoir in Pangani River Basin. Nile Basin Water Science and Engineering, 3, 25-38.

[4] Mohammadi, T.A. (2011) Proposing a Model for Preparation of the Soil-water Erosion Types’ Maps. Scientific Research and Essays, 6, 3139-3147.

[5] Oldeman, L.R., Hakkeling, R.A. and Sombroek, W.G. (1991) Global Assessment of Soil Degradation (GLASOD): World Map of the Status of Human-Induced Soil Degradation. United Nations Environment Programme, International Soil Reference and Information Centre, Nairobi.

[6] Peart, M.R. and Walling, D.E. (1988) Techniques for Establishing Suspended Sediment Sources in Two Drainage Basins in Devon, UK: A Comparative Assessment. Sediment Budgets, Proceedings of the Porto Alegre Symposium, De- 
cember 1988, IAHS Publ. No. 174, 269-279.

[7] Minella, J. P. G., Merten, G. H., and Clarke, R.T. (2004) Identification of Sediment Sources in a Small Rural Drainage Basin. Sediment Transfer through the Fluvial System, Proceedings of a Symposium held in Moscow, August 2004, IAHS Publ. 288, 44-51.

[8] Yanda, P. Z. (1995) Temporal and Spatial Variations of Soil Degradation in Mwisanga Catchment, Kondoa, Tanzania. PhD Dissertation Series No. 4, Department of Physical Geography, Stockholm University, Stockholm, 136.

[9] Williams, G.P. (1989) Sediment Concentrations versus Water Discharge during Single Hydrologic Events in Rivers. Journal of Hydrology, 111, 89-106. http://dx.doi.org/10.1016/0022-1694(89)90254-0

[10] Ndomba, P.M. (2007) Modelling of Erosion Processes and Reservoir Sedimentation Upstream of Nyumba Ya Mungu Reservoir in the Pangani River Basin. PhD Thesis in Water Resources Engineering, University of Dar es Salaam, Dar es Salaam.

[11] Ndomba, P.M. (2013) Validation of PSIAC Model for Sediment Yields Estimation in Ungauged Catchments of Tanzania. International Journal of Geosciences, 4, 1101-1115. http://dx.doi.org/10.4236/ijg.2013.47104

[12] Molina, A. (2009) A Report on Soil Erosion Processes in the Nile Basin. Consultancy within the Framework of the Nile/FRIEND Project Supported by United Nations Educational, Scientific and Cultural Organization (UNESCO).

[13] ISRIC, The International Soil Reference and Information Centre (2014) Global Assessment of Human-Induced Soil Degradation. ISRIC-World Soil Information. http://www.isric.org/projects/global-assessment-human-induced-soil-degradation-glasod

[14] StatSoft, Inc. (2014) Electronic Statistics Textbook (Electronic Version). StatSoft, Tulsa. http://www.statsoft.com/textbook/

[15] Arnold, J.G., Williams, J.R. and Maidment, D.R. (1995) Continuous-Time Water and Sediment-Routing Model for Large Basins. Journal of Hydrology Engineering, 121, 171-183. http://dx.doi.org/10.1061/(ASCE)0733-9429(1995)121:2(171)

[16] Wischmeier, W.H. and Smith, D.D. (1965) Predicting Rainfall-Erosion Losses from Cropland East of the Rocky Mountains, Agriculture Handbook, 282. US Department of Agriculture, Agriculture Research Service, Washington DC.

[17] Williams, J.R. (1975) Sediment-Yield Prediction with Universal Equation Using Runoff Energy Factor. In: Present and Prospective Technology for Predicting Sediment Yield and Sources, US Department of Agriculture, Agriculture Research Service, Washington DC, 244-252.

[18] Bagnold, R.A. (1977) Bed Load Transport in Natural Rivers. Water Resources Research, 13, 303-312. http://dx.doi.org/10.1029/WR013i002p00303

[19] Mulengera, M.K. and Payton, R.W. (1999) Estimating the USLE-Soil Erodibility in Developing Tropical Countries. Tropical Agriculture (Trinidad), 76, 17-22.

[20] Pacific Southwest Inter Agency Committee (PSIAC) (1968) Factors Affecting Sediment Yield in the Pacific Southwest Area and Selection and Evaluation of Measures for Reduction of Erosion and Sediment Yield. Water Management Subcommitte on American Society of Civil Engineers (ASCE), Report No. HY 12.

[21] Alder, H.L. and Roessler, E.B. (1972) Introduction to Probability and Statistics. Fifth Edition. W. H. Freeman and Company, New York, 373 p.

[22] Santhi, C.G., Arnold, J.R., Dugas, W.A., Srinivasan, R. and Hauck, L.M. (2001) Validation of the SWAT Model on a Large River Basin with Point and Nonpoint Sources. Journal of America Water Resources Association, 37, 1169-1188. http://dx.doi.org/10.1111/j.1752-1688.2001.tb03630.x 